\title{
A STUDY OF THE SILVER VOLTAMETER.
}

By K. E. Guthe.

Considering the important rôle which the silver voltameter plays in electrical measurements, relatively few investigations have recently been made with a view of improving the accuracy of this instrument. The older investigations of Kohlrausch, ${ }^{a}$ Rayleigh and Sidgwick, ${ }^{b}$ Gray, ${ }^{c}$ Schuster and Crossley, ${ }^{d}$ and of Glazebrook and Skinner, ${ }^{e}$ proved the silver voltameter to be more reliable than the copper voltameter, and this led to the general use of the well-known form, the specifications of which have been adopted in connection with the legal definition of the ampere, and are practically identical in the United States, ${ }^{f}$ England, ${ }^{g}$ and Germany. ${ }^{h}$ This type has consequently been used, sometimes with only slight modifications, in a large number of investigations; but as the demands upon the accuracy of the results increased, it became more and more apparent that it presented a number of peculiarities, and the thorough researches on the behavior of this voltameter by Kahle ${ }^{i}$ and others soon created the impression that the results obtained with a silver voltameter can not lay any claim to a high degree of accuracy.

Until recently the attempts to find the source of trouble in the voltameter have been rather unsuccessful, different investigators arriving at different conclusions regarding the influence and nature of the disturbing factors. While it must be conceded that in two voltameters of the usual form, when arranged in series and treated in exactly the same manner, the same quantity of electricity will yield deposits differing in weight not more than 1 in 5,000 , or even 1 in 10,000;

$a$ F. and W. Kohlrausch: Wied. Ann., 27, p. 1; 1886.

$b$ Rayleigh \& Sidgwick: Phil. Trans. Roy. Soc., 175, p. 411; 1884.

c Th. Gray: Phil. Mag., 22, p. 389; 1886.

$d$ Schuster \& Crossley: Proc. Roy. Soc., 50, p. 344; 1892.

$e$ Glazebrook \& Skinner: Phil. Trans. Roy. Soc., 183, p. 567; 1892.

$f$ Nat. Acad. of Sci., Feb. 20, 1895.

$g$ (London) Electrician, 27, p. 325; 1891.

h ZS. f. Instrk., 21, p. 180; 1901.

$i$ Kahle: ZS. f. Instrk., 18, pp. 229, 267; 1898. 
these same instruments, when used under slightly differing and frequently under apparently the same conditions, will show much larger differences in a series of independent experiments.

At this point Richards, Collins, and Heimrod, ${ }^{a}$ and Leduc ${ }^{b}$ took up the problem of improving the silver voltameter or coulometer, a name which Richards proposes for the instrument and which, I think, would be much more appropriate.

Since so far the research of Richards and his students is the only one in which a systematic comparison of various types has been made, it seemed of sufficient importance to partly repeat the work with such modifications as seemed advisable, and, after having found the most reliable form, to subject it to a severe test in order to determine the degree of accuracy which may be expected from it.

\section{Description of the Voltameters and their Treatment.}

The following types were investigated:

1. The usual type, consisting of a platinum bowl $10 \mathrm{~cm}$ in diameter and $5 \mathrm{~cm}$ deep as kathode and a silver plate held by a silver rod at its center as anode. The anode was surrounded by filter paper secured at the back with a little sealing wax. The electrolyte, unless otherwise stated, was a neutral freshly prepared 20 per cent solution of silver nitrate.

To test the neutrality of the solution, the silver was precipitated by $\mathrm{NaCl}$ solution and the filtrate tested with methylorange. Silver nitrate, obtained from Eimer and Amend as chemically pure, contained no acid. In a few cases the crystals were first fused to insure neutrality, but since it was found that the results obtained with a solution of the fused salt agreed closely with those where the solution was made from crystals, the latter was used in almost all experiments.

2. The silver oxide voltameter.-Patterson and Guthe ${ }^{c}$ employed as electrolyte a solution saturated with $A g_{2} O$. To allow the oxide to have as great an influence as possible the voltameter was constructed in such a manner that the current had to pass through a layer of the oxide. For this purpose the anode was placed inside a porous cup glazed at the side, at the bottom of which a layer of carefully prepared $\mathrm{Ag}_{2} \mathrm{O}$ was placed. Since the glazing showed a tendency to crack, an ordinary porous cup was used in the later experiments, and a tightfitting glass tube inserted in it, in order to prevent the current from

$a$ Richards, Collins, and Heimrod: Proc. Am. Acad., 35, p. 123; 1899. Richards and Heimrod: Proc. Am. Acad., 37, p. 415; 1902.

$b$ Leduc: J. de Phys., 1, p. 561; 1902.

cPatterson and Guthe: Phys. Rev., 7, p. 257; 1898. 
passing through the sides. The liquid was a 20 per cent solution of silver nitrate kept in a bottle containing silver oxide. Either platinum bowls or platinum crucibles served as kathodes.

3. The Richards voltameter, consisting of a platinum crucible $10 \mathrm{~cm}$ high and $6 \mathrm{~cm}$ wide as kathode. The anode, a silver rod, was surrounded by a fine-grained porous cup, made from the lower end of a Pasteur filter. The electrolyte was the same as in type 1. During the experiment the liquid in the porous cup was always kept at a lower level than that outside by removing about every ten or fifteen minutes some of the liquid in the cup by means of a pipette. Once a siphon was employed to produce this difference in level, without, however, changing the result.

A slight and somewhat more convenient modification of this type will be described later.

4. Large silver anode type.-A platinum bowl formed the kathode. In the 20 per cent solution of silver nitrate a porous cup of $7 \mathrm{~cm}$ diameter was suspended, and, at the bottom of this, finely divided silver was placed, the current being led into the voltameter by means of a plate pressed upon the silver. At first the fine crystals deposited at the kathode in previous runs were used, but it was soon found that the silver became packed so closely that it acted like an ordinary plate; therefore, in the later, final, experiments granulated silver, prepared from the crystals, was substituted and upon this the plate was pressed.

5. Leduc's form differs from type 4 principally by the use of filter paper and muslin to hold the granules on the anode. Granulated silver was heaped upon a plate, $6 \mathrm{~cm}$ in diameter, then covered by pure filter paper and held tight on the plate by bleached millinet. This forms the anode. In all other respects this voltameter is identical with type 1.

The silver was either pure silver obtained from the United States Mint or silver bought from Eimer and Amend as chemically pure. While the results obtained with the two kinds agreed well with each other, the appearance of the anodes after the experiment showed a striking difference. While the finely divided silver which covers the pure anode after electrolysis is whitish and crystalline, the less pure silver from Eimer and Amend is perfectly black, the layer consisting mainly of silver. This difference in the appearance of the anode allows a good estimate of the purity of the silver used and has been noticed before in the work of the Reichsanstalt. ${ }^{a}$

The porous cups were treated with aqua regia, potassium cyanide solution, nitric acid, and finally with boiling water before being used 
in the voltameters. After a few runs the cups become dark on the outside, due to.a thin layer of finely divided silver, which can, however, easily be removed by potassium cyanide. For the large silver anode type, closely grained cups of very convenient shape were obtained from the Akron Insulator and Marble Company.

The use of filter paper was carefully avoided in the preparation of the solution, since it seems that the organic substances act chemically upon neutral silver nitrate solution. ${ }^{a}$. It was not filtered, but transferred from its bottle to the voltameters by means of a clean pipette. Only in types 1 and 5 was filter paper used during the experiment, since it is characteristic for these forms.

The treatment of the silver voltameters was in all cases identical. The platinum bowls, or crucibles, were washed successively with nitric acid, water, then heated to $160^{\circ} \mathrm{C}$. in an air bath, and, after having cooled in a desiccator for an hour or two, carefully weighed. After the experiment the deposits were washed four or five times with distilled water, until the last wash water did not show a bluish color on addition of $\mathrm{NaCl}$ solution. Then the vessels were left over night filled with distilled water well covering the deposit, were emptied in the morning, heated to $160^{\circ} \mathrm{C}$., cooled, and weighed as before. The weight of the deposit for each run was about 4 grams. Usually silver was deposited twice in the same vessel, after which most of it was removed by scraping and the rest dissolved in nitric acid.

It was not deemed necessary to wash the deposit with water at $80^{\circ} \mathrm{C}$., as has been recommended by the Reichsanstalt. Though $\mathrm{Kahle}^{b}$ and Merrill ${ }^{c}$ have found that silver is slightly soluble in hot water, Richards, Collins, and Heimrod, ${ }^{d}$ as well as Leduc, ${ }^{e}$ have shown that after proper washing the weight of the deposit does not change upon continued digestion with water of room temperature, a conclusion fully corroborated by my experience.

Great care was taken to guard against any loss of silver during the washing of the deposit. The solution, as well as the wash water, was always first emptied into a clean beaker. With proper illumination even minute particles of silver could be seen very distinctly. If any were present they were carefully collected in a small filter and later added to the deposit.

Lord Rayleigh and Richards have found that in spite of careful washing some of the mother liquid remains included in the interstices between the crystals, shown by a slight loss of weight on heating to dull redness, but Gray ${ }^{f}$ was unable to observe any loss in deposits

a ZS. f. Instrk., 22, p. 156; 1902.

${ }^{b}$ Loc. cit., p. 233.

c Merrill: Phys. Rev., 10, p. 170; 1900. $d$ Loc. cit., p. 139.

e. Leduc: C. R., 135, p. 24; 1902.

$f$ Gray: Phil. Mag. 22, p. 399; 1886. 
properly washed. At any rate the amount included can only be very slight and must be rather constant, considering how accurate the results are with properly constructed voltameters. Therefore the deposit was not heated in my experiments. The weighings were made with a good chemical balance, having a sensitiveness of about 20 divisions for the load used. It was found advisable to keep two shallow dishes with calcium chlorid in the balance case in order to prevent condensation of moisture on the deposit. In each experiment four voltameters were arranged in series, namely, a set of two bowls, agreeing in weight within $4 \mathrm{mg}$ (55.24 grams each), and a set of two crucibles, agreeing to within $7 \mathrm{mg}$ (39.10 grams each). Each vessel of a set was first weighed separately by the method of double weighing, and then the difference between the two was found by the same method. The latter always agreed with the difference between the two separate determinations within $0.06 \mathrm{mg}$. From these data the probable weight of each vessel was calculated.

The vessels were counterpoised by platinum, so as to avoid troublesome corrections for the buoyancy of air, and the weights used were platinum weights, standardized by the Section of Weights and Measures of the Bureau.

\section{Description of the Method.}

The arrangement of the apparatus is represented by the figure. 'The current was furnished by a storage battery of 40 cells, $B$, and in series with it were placed a large variable resistance, $r_{1}$, the four voltameters, $V$, and standard resistance coil, St. $R$. The small resistance $r_{2}$ was shunted by a Kelvin rheostat, $r$. This consists of a wire wound upon two cylinders, of which one is of metal and the other one insulating. By rotating the cylinders the wire is transferred from one cylinder to the other and the resistance of the rheostat varied in a continuous manner. By the use of this instrument slow variations of the current can easily be avoided. In a shunt to the standard resistance, a sensitive galvanometer, $G$, and a Weston cell, St. $C$., were placed, the latter so as to oppose the potential difference at the terminals of the standard resistance; equality between the two is indicated by the galvanometer remaining at rest. An unsaturated Weston cell was selected on account of its negligible temperature coefficient. The same cell was used throughout the investigation. For the determination of its $E . M . F$. in terms of the standard of the Bureau and for the measurement of the standard resistances and their temperature coefficient I am indebted to the Section of Resistance and Electromotive Force. 
The current is first closed through the resistance $R$, which was made as nearly equal as could be estimated to that of the voltameters, then adjustment was made for no deflection of the galvanometer by varying the resistance of the circuit, and finally, after the current had become practically constant, it was sent for a definite time through the voltameters by throwing the switch 1 . By rotating the Kelvin rheostat the current was kept constantly adjusted to its proper value, until the experiment was completed.

Standard resistances of $1,2.5$, and 10 ohms were used in St. $R$.,

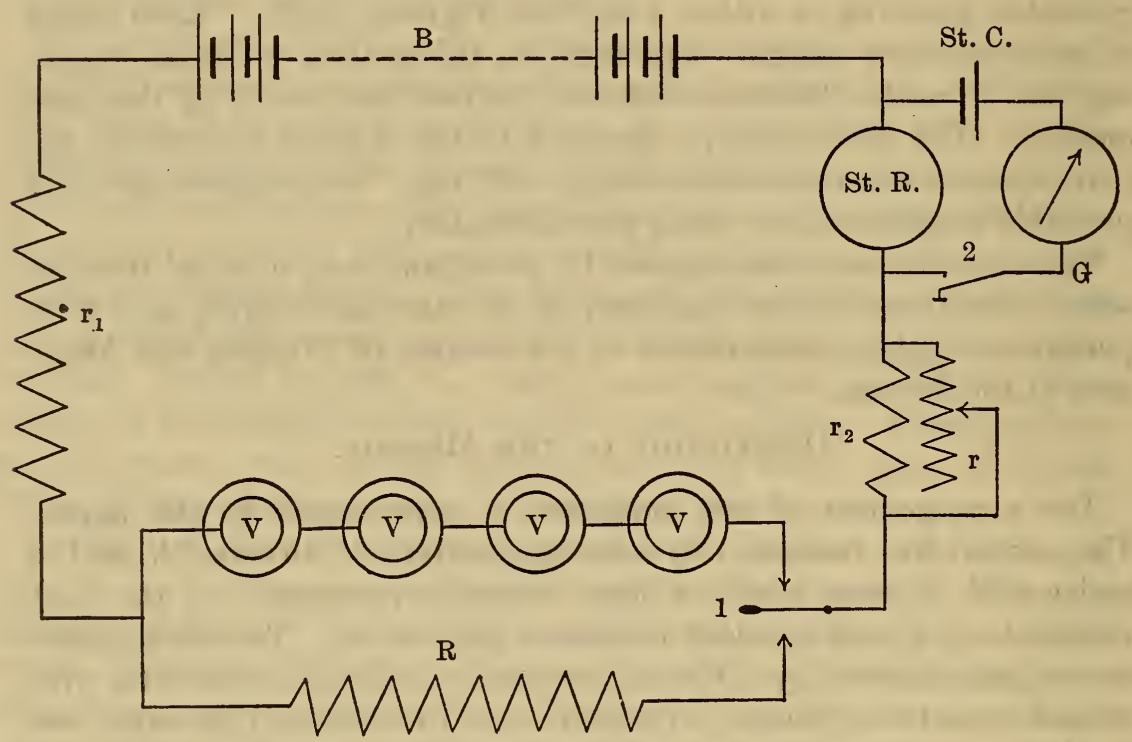

and once the 1 and the 2 ohms were placed in parallel. Thus the current was varied in the different experiments from 0.1 to 1.5 ampere. The current was usually kept closed long enough to allow one ampere hour to pass through the voltameters-i. e., each time about 4 grams of silver were deposited. A change of the current as small as 1 in 100,000 could easily be seen on the scale. In the final determinations of the electrochemical equivalent only such experiments were used in which the variations of the current did not exceed 1 in 25,000 .

The time was measured by an astronomical clock, connected with a chronograph, which also recorded the making and breaking of the current through the voltameters. The rate of the clock was determined by means of the noon signals received from the Naval Observatory.

In a number of experiments the variations of the current exceeded 
the required limit, due partly to the inconstancy of the storage battery, partly to variations in the resistance of the voltameters or the circuit. In some cases the rate of the clock was not known to a sufficient degree of accuracy or the resistance of the voltameters was not estimated correctly. Experiments in which such troubles occurred could not be used for the final calculation, but they allow relative comparisons of the different types of voltameters.

For convenience the Weston cell was not placed directly in the shunt from the standard resistance, but a potentiometer was introduced, the Weston cell balanced over a resistance of 10,190 ohms and then the terminal potential difference of the standard resistance substituted for the cell. Of course the constancy of the auxiliary current through the potentiometer was frequently checked by reconnecting with the standard cell.

\section{COMPARISON OF DIFFERENT VOLTAMETERS.}

In the following tables the results obtained are given. Table I shows that two voltameters of the same type and treated in precisely the same manner will yield deposits which will in general not differ from each other by more than 1 in 10,000.

TABLE 1 .

\begin{tabular}{|c|c|c|c|c|c|}
\hline \multicolumn{3}{|c|}{ Richards type. } & \multicolumn{3}{|c|}{ Usual type. } \\
\hline 1. & 2. & Difference. & 1. & 2. & Difference. \\
\hline $\begin{array}{l}4.09927 \\
4.09955 \\
4.09851 \\
4.09927\end{array}$ & $\begin{array}{l}4.09911 \\
4.09959 \\
4.09870 \\
4.09941\end{array}$ & $\begin{array}{l}\text { Per cent. } \\
-0.004 \\
+.001 \\
+.007 \\
+.003\end{array}$ & $\begin{array}{l}4.09973 \\
4.10003 \\
4.10154 \\
4.10100\end{array}$ & $\begin{array}{l}4.09945 \\
4.09961 \\
4.10098 \\
4.10247\end{array}$ & $\begin{array}{l}\text { Per cent. } \\
-0.007 \\
-.010 \\
-.014 \\
+.036\end{array}$ \\
\hline \multicolumn{3}{|c|}{$\mathrm{Ag}_{2} \mathrm{O}$ type. } & \multicolumn{3}{|c|}{ Large anode type. } \\
\hline 1. & 2. & Difference. & 1. & 2. & Difference. \\
\hline $\begin{array}{l}\text { 4. } 09913 \\
\text { 4. } 10382\end{array}$ & $\begin{array}{l}4.09935 \\
4.10392\end{array}$ & $\begin{array}{l}\text { Per cent. } \\
+0.006 \\
+.002\end{array}$ & $\begin{array}{l}4.10082 \\
4.09891 \\
4.10172\end{array}$ & $\begin{array}{l}4.09985 \\
4.09888 \\
4.10167\end{array}$ & $\begin{array}{l}\text { Per cent. } \\
-0.001 \\
-.001 \\
-.001\end{array}$ \\
\hline
\end{tabular}


The usual form does not show nearly as constant results as the other three. The last large difference may, however, be due to loss of silver in one bowl.

Tables 2 to 8 allow a comparison between the different types, when the same quantity of electricity is sent through them. In the first column of each table the current is given and in the last the percentage difference between the two forms. The asterisks denote that the deposit is on silver, i. e., that it is a second deposit.

TABLE 2.

\begin{tabular}{|c|c|c|c|}
\hline Current. & Richards type. & Usual type. & Difference. \\
\hline & & & $\begin{array}{c}\text { Per cent. } \\
+0.070\end{array}$ \\
0.1 & 4.09863 & $4.10150^{*}$ & +.057 \\
0.2 & $4.09993^{*}$ & 4.10225 & +.062 \\
0.5 & 4.09870 & $4.10126^{*}$ & +.036 \\
1.0 & 4.09800 & 4.09973 & +.042 \\
1.0 & $4.09927^{*}$ & 4.10100 & +.050 \\
1.0 & $4.09941^{*}$ & 4.10247 & +.030 \\
1.0 & 4.09881 & 4.10016 & +.039 \\
1.0 & 4.09896 & 4.10056 & +.048 \\
\hline
\end{tabular}

TABLE 3.

\begin{tabular}{|c|c|c|c|}
\hline Current. & Richards type. & $\mathrm{Ag}_{2} \mathrm{O}$ type. & Difference. \\
\hline & & & Per cent. \\
\hline 0.1 & 4. 09863 & 4. 10147 & +0.069 \\
\hline 0.5 & 4. 09881* & 4. 10053 & +.042 \\
\hline 1.0 & 4. 09881 & 4. 10167 & +.070 \\
\hline 1.5 & 4. 09897 & 4. $10091^{*}$ & +.047 \\
\hline \multicolumn{3}{|c|}{ Average. } & +.055 \\
\hline
\end{tabular}


TABLE 4.

\begin{tabular}{|c|c|c|c|}
\hline Current. & Richards type. & Leduc type. & Difference. \\
\hline $\begin{array}{l}0.2 \\
0.5\end{array}$ & $\begin{array}{l}\text { 4. } 09920 \\
\text { 4. } 09906^{*}\end{array}$ & $\begin{array}{l}\text { 4. } 10245 \\
\text { 4. } 10141^{*}\end{array}$ & $\begin{array}{l}\text { Per cent. } \\
+0.057 \\
+.057\end{array}$ \\
\hline \multicolumn{3}{|c|}{ Average .. } & +.057 \\
\hline
\end{tabular}

TABLE 5.

\begin{tabular}{|c|c|c|c|}
\hline Current. & Large anode type. & $\mathrm{Ag}_{2} \mathrm{O}$ type. & Difference. \\
\hline & & & Per cent. \\
\hline 1.0 & 4. 10172 & 4. $10382 *$ & +0.051 \\
\hline 1.0 & 4. 10167 & 4. $10392^{*}$ & +.055 \\
\hline \multicolumn{3}{|c|}{ Average . } & +.053 \\
\hline
\end{tabular}

TABLe 6.

\begin{tabular}{|c|c|c|c|}
\hline Current. & Usual type. & $\mathrm{Ag}_{2} \mathrm{O}$ type. & Difference. \\
\hline & & & Per cent. \\
\hline 0.1 & 4. 10150 & 4. 10147 & -0.001 \\
\hline 0.2 & 4. $10003^{*}$ & 4. 09913 & -.022 \\
\hline 0.2 & $4.09961^{*}$ & 4. 09935 & -.006 \\
\hline 1.0 & 4. 10016 & 4. 10167 & +.038 \\
\hline \multicolumn{3}{|c|}{ Average . } & +.002 \\
\hline
\end{tabular}


TABLE 7.

\begin{tabular}{|c|c|c|c|}
\hline Current. & Richards type. & Large anode type. & Difference. \\
\cline { 2 - 3 } & & & Per cent. \\
0.2 & $4.09993^{*}$ & 4.09962 & -0.007 \\
0.5 & $4.09881^{*}$ & 4.09889 & +.002 \\
0.5 & $4.09906^{*}$ & $4.09919 *$ & +.003 \\
1.0 & 4.10449 & 4.10468 & +.005 \\
1.0 & 4.10461 & 4.10510 & +.012 \\
1.0 & 4.09919 & 4.09912 & -.002 \\
1.0 & 4.11888 & 4.11902 & +.004 \\
1.0 & $3.47004^{*}$ & 3.47053 & +.014 \\
1.5 & 4.09897 & $4.09880^{*}$ & -.004 \\
\hline
\end{tabular}

TABLE 8.

\begin{tabular}{|c|c|c|c|}
\hline Current. & Richards type. & $\begin{array}{c}\text { Richards type } \\
\text { (modified). }\end{array}$ & Difference. \\
\hline & & & Per cent. \\
& & 0.005 \\
0.2 & 4.09920 & 4.09942 & -.002 \\
0.5 & $4.09906^{*}$ & $4.09896^{*}$ & -.003 \\
1.0 & $3.47004^{*}$ & $3.46998^{*}$ & -.004 \\
1.0 & 4.09896 & 4.09881 & -.008 \\
1.0 & 4.11888 & 4.11857 & -.002 \\
\hline
\end{tabular}

From these tables it can be seen that there are two distinct classes of voltameters, on one side the usual, Leduc's, and the silver oxide type, on the other the Richards and the large anode type, the latter class yielding deposits about 0.05 per cent smaller than the former.

The difference between the usual form and Richards's agrees very well with the final average of 0.050 per cent given by Richards. ${ }^{a}$ A voltameter in which the electrolyte was always kept saturated with $\mathrm{Ag}_{2} \mathrm{O}$ has not been used before. Patterson and Guthe employed a solution saturated before the experiment was made, but in all other respects adhered to the legal specifications. Richards's comparison between his type and Patterson and Guthe's showed for the latter a

$a$ Richards and Heimrod: Proc. Am. Acad., 37, p. 439; 1902. 
deposit 0.112 per cent larger than for the former, besides a considerable variation in the percentage difference (from 0.039 to 0.230 per cent). We see from Table 3 that the form of $\mathrm{Ag}_{2} \mathrm{O}$ voltameter used in the present investigation gives somewhat more concordant results and a much smaller difference between the two types. Possibly the presence of filter paper in the Patterson and Guthe voltameter may explain the greater value. A porous cup has doubtless the effect of decreasing the weight of the deposit.

It must be confessed that the results obtained with Leduc's voltameter were not expected. He has repeatedly asserted that no trouble arises when small anodic current density is employed. As will be seen from Table 4, in these comparisons small currents were used, but the deposit was in each case 0.057 per cent larger than that obtained with the Richards type. A comparison of Tables 3 and 4 verifies Leduc's statement $^{a}$ that a solution saturated with the oxide and a normal solution will give identical results. It was also noticed that even with these small currents the heavy anode liquid sinking to the bottom of the platinum bowl and there spreading produced a starlike figure of the deposit. This peculiar arrangement of the crystals, very characteristic for the usual type, has been studied by Behn, ${ }^{b}$ who showed it to be due to the motion of the heavy anode liquid along the surface of the kathode.

With a porous cup around the anode the crystals are distributed perfectly evenly over the kathode without showing the striæ spoken of. Filter paper allows an easy passage to the anode solution, and should therefore be avoided, even if the chemical action upon neutral nitrate solution, to which attention was drawn above, will not affect the electro-chemical equivalent.

All previous researches on the subject have led to the conclusion that the source of trouble is to be looked for at the anode. The solution becomes acid during electrolysis, and therefore the presence of acid has been suggested as the reason for the inconstancy of the voltameter. Leduc ${ }^{c}$ has shown, however, that a fresh solution, originally neutral, but afterwards slightly acidified, gives smaller deposits than a neutral solution. According to this observation, the presence of acid alone has not the effect of increasing the weight of the deposit. Another interesting observation by the same author shows that if the amount of acid surpasses a certain limit in the original solution, its density will decrease during electrolysis, a fact observed before by

$a$ Leduc: Rapp. Congr. intern., 2, p. 444; Paris, 1900.

$b$ Behn: Wied. Ann., 51, p. 105; 1894.

$c$ Leduc: J. de Phys., 1, p. 573; 1902. 
Rodger and Watson. ${ }^{a}$ The latter seem to be the first to have pointed out that during electrolysis a complex silver ion may be formed and that this may produce too heavy deposits. The thorough work of Richards and his students have strengthened this view and my own results seem all to point to the same explanation. The existence of such a complex ion, whatever it may be, ${ }^{b}$ would easily enough explain the formation of the acid at the anode. It is well known that, during electrolysis of silver nitrate solution, crystals are formed at a platinum anode, which according to Sulc ${ }^{c}$ and Mulder and Heringa ${ }^{d}$ have the formula $\mathrm{Ag}_{7} \mathrm{NO}_{11}$. I have been able to obtain these bluish-black crystals mixed with silver at the cathode from a solution saturated with $\mathrm{Ag}_{2} \mathrm{O}$, using a large current density. In this case the deposit was abnormally heavy, 0.23 and 0.32 per cent greater than that obtained in a large silver anode voltameter. Complex ions are therefore present in such a solution and it seems reasonable to suppose that if they reach the kathode, as they will in voltameters in which the anode is surrounded by filter paper or in the $\mathrm{Ag}_{2} \mathrm{O}$ type, the deposit will be too heavy, resulting in a wrong value for the electro-chemical equivalent of silver.

Richards's method of removing the heavy anode liquid from the bottom of the porous cup and preventing its diffusion toward the kathode by keeping the level inside lower than the outside is therefore correct, and will not give too small an equivalent, as Leduc asserts.

The large silver anode voltameter gives the same results as Richards's form, in spite of the fact that the solution is at the same level inside and outside. (See Table 7.) How can we explain this? A few experiments by Richards and Heimrod ${ }^{e}$ show that a crucible on which silver had been deposited previously will increase in weight when filled with the anode solution. Apparently a chemical reaction takes place, resulting in a breaking up of the complex ion and a deposition of silver. In the large anode type the porous cup prevents the anode solution from diffusing rapidly, and the silver at the bottom of the cup breaks up the troublesome ion. This secondary chemical reaction, I believe, is the reason why the anode is always covered by a layer of finely divided silver-the "anode dust"- the anode itself acting, to a certain extent, chemically on the ion produced by electrolysis. The

$a$ Rodger and Watson: Phil. Trans., 186, p. 631; 1895.

$b$ Richards suggests $\mathrm{Ag}_{3} \mathrm{O}$. See also the theoretical discussion between Revay and Küster and von Steinwehr: ZS. f. Electroch., 4, pp. 313, 451; 1898.

$c$ Sulc: ZS. f. anorg. Chem., 12, p. 90; 1896.

$d$ Mulder and Heringa: Verh. Kon. Ak. Wet., 3, p. 37; 1896.

- Richards and Heimrod: loc. cit., p. 431. 
large anode type will therefore give as good results as the Richards type and is more convenient to use.

The above considerations led the author to the construction of a modified Richards voltameter. Instead of removing the liquid from the bottom, some of the silver crystals deposited by previous runs were placed in the bottom of the cup and the liquid was left undisturbed during the experiments. At first some inconvenience was experienced, due to the rapid growth of the silver toward the anode and consequent sudden changes in the resistance of the voltameter, which prevented the proper adjustment of the current to a constant value. But this trouble was overcome entirely by surrounding the lower part of the porous cup by a small glass cup cut from a test tube or a small beaker. The excellent agreement with Richards's form (see Table 8) shows that also this modification will give the correct silver equivalent.

It is therefore proposed to abandon in future experiments, especially for the absolute measurement of current, the usual form of the silver voltameter and employ either Richards's type or one of those proposed by the author. The differences in the weight of silver obtained by two of these voltameters in series show much smaller variations than those by the old form, and, as will be seen in the following, determinations made by means of independent experiments agree very closely.

\section{Silver Nitrate Solution-Deposit on Platinum and on Silver.}

It has been shown by Kahle that an old solution will yield too heavy deposits, its effect increasing as more and more silver is electrolysed. The Reichsanstalt advises, therefore, to use the solution only until 3 grams of silver are deposited from $100 \mathrm{~cm}^{3}$ of solution. It seemed to be of interest to see whether in the Richards form the solution outside of the porous cup could be used repeatedly. Eight grams of silver were deposited by two runs from the same solution, amounting to about $150 \mathrm{~cm}^{3}$, and the solution left standing for several weeks. In the experiments following two Richards voltameters were placed in series, one with a fresh solution, one with this old solution. The latter gave on the average 0.055 per cent more silver. Now, it was thought that it might be possible to obtain a good solution by leaving it in contact with silver crystals. After several weeks more this solution was tried again and gave on the average 0.025 per cent heavier deposits than the Richards form. While an improvement is to be observed, it is clear that keeping the solution simply in contact with silver will not entirely eliminate the complex ion. It is therefore advisable to use always freshly prepared silver nitrate solution. Variations in 
concentration have been shown by former investigators to be of no influence upon the weight of the deposit. In our case the electrolyte was always a 20 per cent solution.

Gore $^{a}$ and Kahle found a somewhat larger deposit when the kathode was used a second time before removing the silver collected in a previous run; and Richards and Heimrod corroborate their statement so far as the filter-paper voltameter is concerned, but found no difference with the porous-cup voltameter. Patterson and Guthe obtained the same deposit on platinum and on silver. Table 9 gives the results of tests made with this point in view.

TABLE 9.

\begin{tabular}{|c|c|c|c|c|c|c|}
\hline & \multicolumn{3}{|c|}{ Richards type. } & \multicolumn{3}{c|}{ Large anode type. } \\
\cline { 2 - 6 } Current. & $\begin{array}{c}\text { On } \\
\text { platinum. }\end{array}$ & On silver. & $\begin{array}{c}\text { Differ- } \\
\text { ence. }\end{array}$ & $\begin{array}{c}\text { On } \\
\text { platinum. }\end{array}$ & On silver. & Difference. \\
\cline { 3 - 7 } & & & Per cent. & & & Per cent. \\
Amperes. & & & & & \\
1.0 & 3.70837 & 3.70850 & +0.003 & 3.70879 & 3.70839 & -0.011 \\
1.0 & 4.10461 & 4.10449 & -.003 & 4.10468 & 4.10510 & +.011 \\
\hline
\end{tabular}

It is apparent that it makes no difference whether a clean platinum kathode is used or whether the silver from previous runs is left on it. Of course the deposit should not become too heavy, on account of the increasing danger of mother liquid remaining included in the interstices between the crystals.

The explanation for the heavier deposits on silver in the filter-paper voltameter is to be sought in the action of the silver upon the anode liquid.

\section{Electro-Chemical Equivalent of Silver.}

In conclusion, the results are given of experiments which were suited for the calculation of the electro-chemical equivalent of silver in terms of the electrical standards of the Bureau. According to legal specifications the E. M. F. of a Clark cell at $15^{\circ} \mathrm{C}$. is 1.434 volts. The unsaturated Weston cell was found to have an E. M. F. of 1.01954 volts. The resistance standards have been repeatedly intercompared with those of the Reichsanstalt.

In Table 10 the amount of silver deposited by one ampere hour and under the condition that the terminal potential difference of the resist- 
ance was equal to the $E$. M. $F$. of the Weston cell is given for the different forms.

TABLE 10.

\begin{tabular}{|c|c|c|c|c|}
\hline Current. & $\begin{array}{l}\text { Richards } \\
\text { type. }\end{array}$ & $\begin{array}{c}\text { Richards } \\
\text { type } \\
\text { (modified). }\end{array}$ & $\begin{array}{l}\text { Large anode } \\
\text { type. }\end{array}$ & Usual type. \\
\hline Amperes. & Grams. & Grams. & Grams. & Grams. \\
\hline 0.5 & 4. 09881 & & 4. 09888 & 4. 10154 \\
\hline 0.5 & 4. 09906 & 4. 09896 & 4. 09891 & 4. 10098 \\
\hline 0.5 & 4. 09870 & & ........ & \\
\hline 1.0 & 4. 09881 & 4. 09881 & & 4. 10016 \\
\hline 1.0 & 4. 09896 & & & 4. 10056 \\
\hline 1.5 & 4. 09897 & & 4.09880 & \\
\hline Average .... & 4.09888 & 4. 09888 & 4. 09888 & 4. 10081 \\
\hline 0.2 & 4. 09920 & 4. 09942 & 4. 09952 & \\
\hline 0.2 & 4. 09955 & & 4. 09985 & \\
\hline 0.2 & 4. 09959 & & 4. 09962 & - \\
\hline 0.2 & 4. 09993 & & ...... & \\
\hline
\end{tabular}

It is seen that the agreement between these independent experiments is a surprisingly good one, the largest differences amounting to less than 1 in 10,000 in the first three types, as long as the current is equal or larger than 0.5 ampere. For 0.2 ampere the deposits are invariably greater. This is not surprising. The current in these cases was closed five hours, and in spite of all precautions some of the anode liquid probably diffuses through the porous cup during that time. This explanation seems the more plausible from the results obtained in the Richards form with 0.2 ampere. In the first experiment of the four the anode liquid was removed every ten minutes, in the next two every fifteen to twenty minutes, and in the last every. half hour. The increase of the weight of the deposit with the opportunity of the liquid to penetrate the porous partition is apparent. The current should therefore be closed not longer than two hours, this of course depending to a certain extent upon the grain of the porous cup.

To obtain the electrochemical equivalent of silver we have to divide the deposit, 4.09888 grams, by $1.01954 \times 3,600$. This gives $1.11675 \mathrm{mg}$ per coulomb; but the silver was weighed with platinum weights, and 
therefore a correction of +0.0069 per cent should be applied for the buoyancy of air. Thus the final result for the silver equivalent is

\section{$1.11683 \mathrm{mg}$ per coulomb.}

With a filter-paper voltameter the corresponding results would be 0.048 per cent higher, or $1.11736 \mathrm{mg}$. Kahle's comparison between the $E . M . F$. of the Clark cell and the electrochemical equivalent of silver reduced to the same value for the $E$. M. $F$. of the Clark cell would give $1.11726 \mathrm{mg}$.

In the following table we find a comparison of the values obtained by different observers, all being reduced to the same units. In the case of Perot and Fabry, ${ }^{a}$ who used a Clark cell at $0^{\circ} \mathrm{C}$. and found its $E$. M. $F$. to be 1.4522 volts, using $1.118 \mathrm{mg}$ as the electrochemical equivalent, the difference of 0.0164 volt, given by the Reichsanstalt, has been used to reduce to $15^{\circ} \mathrm{C}$., instead of the ratio given by them. If the latter is used their results are identical with von Ettinghausen's.

TABLE 11.

\begin{tabular}{|c|c|c|c|}
\hline Name. & Year. & $\begin{array}{l}\text { Filter-paper } \\
\text { voltameter. }\end{array}$ & $\begin{array}{l}\text { Porous-cup } \\
\text { voltameter. }\end{array}$ \\
\hline & & $m g$ & $m g$ \\
\hline Carhart......................... & 1882 & 1.1172 & 1.1167 \\
\hline Rayleigh and Sidgwick .... & 1884 & 1.1183 & 1.1179 \\
\hline Von Ettinghausen .......... & 1884 & 1. 1180 & 1.1175 \\
\hline Glazebrook and Skinner... & 1892 & 1. 11831 & 1.11778 \\
\hline Perot and Fabry ................ & 1898 & 1.1193 & 1.1188 \\
\hline Kahle.......... & 1898 & 1.11726 & 1.11673 \\
\hline Guthe ........... & 1904 & 1.11736 & 1.11683 \\
\hline
\end{tabular}

The large differences in these results can hardly all be due to the silver voltameter alone. No doubt the Clark cell comes in for its share. Carhart's value is based on only two comparisons, with very small silver deposits, and Rayleigh's is the result of only one experiment.

Richards has made an attempt to reduce the absolute measurements of an electric current to the same basis by calculating the electrochemical equivalent under the supposition that the porous cup voltameter had been used, and finds good agreement between the results

$a$ Perot and Fabry: Annal. de fac. de sci., Marseille, 8, p. 201; 1898. 
of Lord Rayleigh and Mrs. Sidgwick, Fr. and W. Kohlrausch, Kahle, and Patterson and Guthe. They all agree within 3 in 10,000 and give the mean value of $1.1175 \mathrm{mg}$.

Since that time two more absolute determinations have been made. The recent one by van Dijk and Kunst using the filter paper voltameter gives 1.1182 (or 1.1177) $\mathrm{mg}$ for the silver equivalent; but Pellat and Luduc obtained $1.1195 \mathrm{mg}$, or, reduced to the same basis, $1.1188 \mathrm{mg}$. Thus, the latest determinations of the electrochemical equivalent still show a difference larger than 1 in 1,000 . 



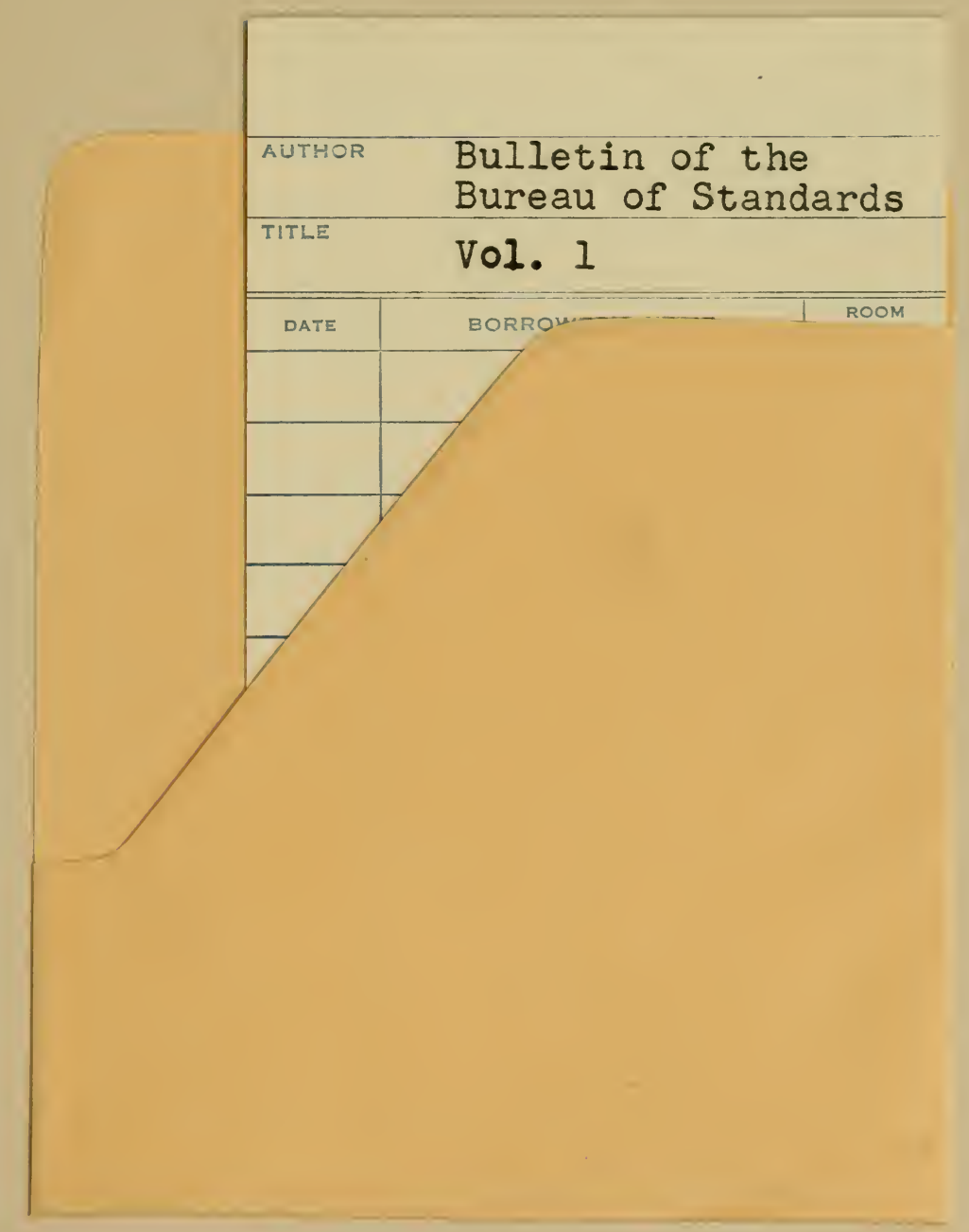


